\section{Governance in the health sector}

Gobernanza en el sector salud

\section{Alvaro Fernando Lopez Cazorla*}

\section{ABSTRACT}

The objective of the article was to analyze the functioning of governance in the health sector in the global and national context; the starting point was a diagnostic Literature Review (RSL) using scientific and institutional articles. The problem is approached from the existence of an evident lack of conceptual coherence in the use of the terms governability and governance (considered synonymous with "governance") in Latin America, both in social and political sciences, as well as in the health domain. This is expressed with wide dynamics in a different understanding of the term governance by researchers, a heterogeneous use in academic circles. Governance constitutes a social fact in itself and can be analyzed from a non-normative and non-prescriptive approach. In itself, it is not a search for a "new model of public management" that is "desirable to promote". There cannot be more or less governance. Every society is endowed with "governance", the characteristics of which evolve over time. There are therefore numerous forms of governance, in history, but still in the present. These different forms can be analyzed and interpreted. They can be described and broken down into their constituent elements in order to understand how they function. To this end, the development of a methodology of analysis that allows the passage between an interpretative framework and empirical observation is proposed.

Keywords: Health Services, Public Health Policies, Social Security, Government Programs.
JOURNAL OF BUSINESS and entrepreneurial studies

ISSN: 2576-097|

Atribución/Reconocimiento-NoCo mercial- Compartirlgual 4.0 Licencia Pública Internacional - CC

BY-NC-SA 4.0

https://creativecommons.org/licenses /by-nc- sa/4.0/legalcode.es

Journal of Business and entrepreneurial January - March Vol. 6 - I - 2022 http://journalbusinesses.com/index.php/revista e-ISSN: 2576-097I journalbusinessentrepreneurial@gmail.com Receipt: 04 March 202I Approval: 09 June 202I

Page I-16

\footnotetext{
* Doctor Universidad Cesar Vallejo, Lima, Perú, alvarolopez518@gmail.comm, https://orcid.org/0000-0003-3963-5786
} 


\section{RESUMEN}

El objetivo del articulo ha sido analizar el funcionamiento de la gobernanza en el sector salud en el contexto mundial y nacional; se parte de un diagnóstico de Revisión de la Literatura (RSL) empleando artículos científicos e institucionales. El problema se aborda desde la existencia de una evidente ausencia de coherencia conceptual en el uso de los términos gobernabilidad y gobernanza (considerado sinónimo de "gobernancia") en América Latina, tanto en ciencias sociales y políticas, como en el dominio de la salud. Lo indicado se expresa con amplia dinámica en una distinta comprensión del término gobernanza por parte de los investigadores, un uso heterogéneo en ámbitos académicos. La gobernanza constituye un hecho social en sí mismo y puede ser analizada a partir de una aproximación no normativa y no prescriptiva. En sí, no se trata entonces de una búsqueda de un "nuevo modelo de gestión pública" que sea "deseable de impulsar". No puede haber mayor o menor gobernanza. Toda sociedad esta dotada de una "gobernanza", cuyas características evolucionan en el tiempo. Existen entonces numerosas formas de gobernanza, en la historia, pero aun en el presente. Estas diferentes formas pueden ser objeto de un análisis y una interpretación. Ellas pueden ser descriptas y desagregadas en sus elementos constitutivos a fin de comprender su funcionamiento. A tales efectos se plantea el desarrollo de una metodología de análisis que permita el pasaje entre un marco interpretativo y la observación empírica.

Palabras clave: Servicios de Salud, Políticas Públicas de Salud, Seguridad Social, Programas de Gobierno.

\section{INTRODUCTION}

The research proposal, has been conducted according to the standards of the Graduate School of the Universidad César Vallejo under a qualitative approach, it is phenomenological, rational-institutional that, on the analysis of documents of national and supranational character such as the Millennium Development Goals, the National Agreement, the Political Constitution of Peru, the pertinent laws and norms, and the health policies set forth in the National Concerted Health Plan (PNCS) and the Multiannual Sectoral Strategic Health Plan (PESEM), attempts to test the hypothesis put forward in reference to the disarticulation of health policies with the governance approach.(Albar \& Miranda, 2020, p. 4I4)

According to Pérez-Escamilla et al., (2017) in such sense, the aspects of health in general in a democratic government, public health policies, political actions and health strategies at the national level are theorized. With which coincides Muñoyerro-Muñiz et al., (2020) who has determined that, for several years, there have been prestigious institutions that proposed valid guidelines to establish an integrated and sustainable health policy. Many of these guidelines have been taken into account in both the PNCS and the PESEM; however, they have not yet been properly implemented and articulated.

Health according to Cuervo \& Bermúdez-Tamayo, (20I8) y (Valdés, 20I6) is one of the problems with the highest social incidence in the world, which in poor countries is usually deficient and of poor quality. Situation, which has had a response from the United Nations through the Millennium Development Goals (MDGs), which synthesize the goals and objectives of human development monitoring that must be achieved in the period 
1990- 2015; For Alcántara-Santuario \& Marín-Fuentes, (2013) This commitment has programs agreed upon by all countries and major institutions of the world dedicated to development, that is, a set of simple but very important objectives that everyone can understand and support without difficulty.

In this sense (Améríco, 2013, p.80) specifically establishes two policies mark the attention with regard to health, one is the 13th State Policy, Universal Access to Health Services and Social Security, which has as its commitment, to ensure the conditions for universal access to health free of charge, continuous, timely and quality, with priority in areas of poverty concentration and in the most vulnerable populations.

Promote citizen participation in the management and evaluation of public health services and the 15th State Policy, Promotion of Food Security and Nutrition, which states the establishment of a food security policy that allows the availability and access of the population to sufficient and quality food, to ensure an active and healthy life within a concept of integral human development.

In this context, the thesis entitled Governance in the Health Sector is developed. Regarding the formulation of the general problem, it has been established as follows: How to strengthen the Governance in the Health Sector in articulation with the public health policy, in relation to the specific problems, they have been established as follows: specific problem I

How to apply the norms of Health Governance articulating them with the public health policy, specific problem 2 How to apply the nodal points of Health Governance articulating them with the public health policy, and specific problem 3 How does the interruption of the Governance processes affect the fulfillment of the public health policy?

Morteruel et al., (202I) justifies the research, it is indicated that governance in the social sectors, particularly in the health sector, should support innovative and massive public health management strategies to face the COVID-19 pandemic through health promotion measures and healthy lifestyles, prevention of contagion and early detection. The active search for the virus with a focus on risk and with mechanisms such as sectorization should consider the territory and population as fundamental instruments. Geolocation and geo-referencing make it possible to break the chain of transmission of the pandemic. Repullo \& Freire, $(2016)$ it is necessary to attend to the healthy, to locate the carriers with a risk approach and to carry out early detection to avoid contagion. For Giné et al., (2020); Díaz-Castro et al., (2017) indicates that the focus of attention should be the community through participatory liaison with community public health agents who are at the same social base, and their preventive work should be reactivated in a social and participatory manner.

The community approach involves reducing the number of sick people. The sub-themes to be addressed in the framework theme are the following:

a) Health governance

b) Recovery of the Ministry of Health's steering role in public health policies.

c) Territorial management through geolocation and geo-referencing that allows to 
break the chain of transmission of the pandemic.

d) Health responsibility and primary health care management.

e) Contagion prevention management.

f) Evaluation of community participation in health.

g) Assessment of healthy lifestyles and determinants of health.

h) New challenges of health policies with the population in times of crisis.

i) Solid health care waste management.

j) Water management.

k) Health education management and social communication in health crises.

l) Management of community health agents. Participation and prevention.

The general objective of the study will be to strengthen governance by articulating it with public health public policy. The specific objectives are: specific objective I. to analyze the norms of Health Governance articulated with the public health policy, specific objective 2. to explain the nodal points of Health Governance articulated with the public health policy, and specific objective 3 . to analyze the interruption of Governance processes in the fulfillment of the public health policy. The hypothesis to be tested will be to explain that the strengthening of governance through strategies and action plans is articulated to the public health policy with the actors involved.

\section{MATERIALS AND METHODS}

According to the approach and consideration of the variables; and, by the type of study, there are characteristic components and the indispensable conditions to be called a descriptive-qualitative study.

Approach: Quantitative.

Health management case studies.

In accordance with the purpose to be explored, it is stated that this is a descriptive study. The study is centered on the positivist paradigm, since it admits only objective criteria. The approach is qualitative; the impact of results-based management in the health field is analyzed.

The variables are management by results and public spending in the health sector.

In the study, the population was determined by the institutions that make up the health sector and that have the capacity to manage the budget.

For the purposes of the research, the sampling will be determined in a probabilistic manner by convenience and a sample of documents managed at the health management level will be taken.

The information search methodology consisted of: I) Collection of studies related to scientific articles, theses, journals, magazines, publications that have been carried out at national and international level, 2) In the space of time, the period of time comprising the search was taken into account with an antiquity of 5 years, 3) In relation to the information, The information is oriented to the dimensions linked to performance budgeting and public spending, 5) Be specific with the terms, that they are quick to 
understand for the reader of the literature review, 6) The scientific articles are explanatory, empirical or applicative studies; and based on this, irrelevant and unnecessary information was excluded and purified.

Once the search for information was completed, a second selection of articles in the systematic review was started. It is a virtual tool that aims to store and disseminate, through its sites, the undergraduate and graduate studies of students and teachers from different universities. The Network of Ibero-American Scientific Journals, which covers all areas of knowledge and in which papers related to budgeting for results were included.

At the end of the research, 20 articles were selected, which were included in the systematic review, for which the importance of the study and reliability of authors on the topic to be carried out, dimensions such as budgeting for results and public spending, which gave priority to national research, were fundamental.

The study was prepared according to the regulations provided by Universidad César Vallejo, in addition to being original and intellectual property, which are mandatory in this type of research.

The relevance of the research is that there is no other similar research work to date, which is based on the analysis of the health system.

\section{RESULTS}

The scope of this article is limited to the development of an initial reflection and proposal for the design of a conceptual-analytical framework for health governance.

For the purposes of its treatment as a scientific concept, governance must refer to a well-delimited social fact and allow its empirical observation by methodologies and techniques recognized as scientific. Although for some authors, governance is in a "prescientific" state and its object in the process of definition (Jessop, 2018), this proposal posits a delimited and observable object. We refer to governance as the processes of collective action that organize the dynamics of actors and social norms, with which a society determines its behavior. A society's behavior refers to the way in which decisions are made and executed in relation to the social whole, and to the arrangements of the actors among themselves. These processes include actors, collective actions and norms, both formal and informal.

In order to study governance, an empirical methodology is needed, and this implies first developing a "governance conceptual framework" (an articulated set of concepts that has a descriptive or analytical purpose with respect to a given object), which serves as a reference for the observation process. An analytical framework is a coherent set of models (schematic representations of a situation) associated with a methodology that allows the passage between the conceptual framework and the empirical observation. This proposal defines certain fundamental criteria: the analytical framework has to be realistic, transdisciplinary, comparative, generalizable, multilevel and reflexive. As mentioned above, "realistic" refers to its capacity to describe the facts as they are, and 
not as they should be, as opposed to normative perspectives. Transdisciplinary character refers here to the interactive work of researchers from multiple disciplines, and to the involvement of stakeholders in the research process. (Aranda \& Rodríguez, 2017, p. 766).

If we assume the impossibility of absolute neutrality of researchers and take into account the multiple references made by different authors on the changes introduced in social situations by the mere fact of observing them, then researchers are considered as actors. This implies a reflexive perspective on the part of researchers, which takes into account their interactions with other actors, and the consequences arising from these contacts. In order to be comparative and generalizable, this methodology also assumes that several governance configurations or models and their differentiated effects on a variable considered as dependent can be measured. This requires the availability of an analytical framework, empirical measurable indicators and appropriate means of observation.

In the perspective of a chain of interactions, governance is considered as an intermediate variable. On the one hand, it produces effects on a dependent variable (e.g., the problem of access to health services), and on the other, it depends on independent variables that determine it (e.g., the institutional organization of the health system). In turn, it is likely that governance is only one factor among others that contributes to explaining the problem under study ("multi-causality").

A central feature of the methodology are the analytical categories or observable dimensions of governance: actors, social norms, nodal points and processes. Actors are individuals or groups. Their collective action (agreements or decisions) leads to the formulation of norms (or rules of the game, or decisions) that guide the actors' behavior and are modified by collective action. Collective action results from the interaction/transaction between actors, whether conflictual or cooperative, from the agreements or decisions that are made and their implementation.

For the purposes of analysis, for a given dependent variable (health budget allocation), we can identify "nodal points" (or "social interfaces"), physical or virtual spaces (e.g., a negotiating table, the federal or state health council, etc.), where various processes, actors and norms converge, producing effects, in isolation or in interaction with others, on the dependent variable under study.

Processes are successions of states through which the interrelationship between actors, norms and nodal points pass. Processes, actors and norms can be formal, i.e. recognized by the authority-bearing actors in the society observed (this recognition is "legal" at the level of societies endowed with positive law), or informal, defined by the practice of the actors. Based on the use of the categories of analysis, the methodology aims to identify how governance influences the selected dependent variables. It attempts to identify whether there are characteristics of the nodal points that are favorable or unfavorable to a change in the problem under study. Presents a simplified example that assumes governance as an independent variable. It is understood that, through the analysis of nodal points and interaction processes (in this case the interaction of 4 nodal points), 
the specific place of intervention (nodal point B) can be identified to achieve a change in the problem under study (inequity).

The proposed methodological approach integrates certain fundamental dimensions that need to be developed as categories of analysis. This section describes the dimensions of governance: actors, norms, nodal points and processes.

Actors

In a dynamic analysis of governance, where norms guide the behavior of actors and are modified by collective action, social norms are intimately linked to actors, their behaviors and interactions and conditioned by their nature, power, interests, ideas and history.

In order to characterize the interrelationships between actors, it is possible to design "a map of strategic actors", to recognize the complexity and nature of the actors involved, their expectations, values and strategies, as constitutive factors of the mechanisms (explicit or implicit) of interaction(Prada Trigo, 20I3, p.9).

In this development it is necessary to consider: the characterization of stakeholders and strategic actors, the resources used by them, and the nature of the transactions involved in such relationships.

Prats' conceptual development of strategic actor allows us to define it in terms of "any individual, organization or group with sufficient power resources to prevent or disrupt the functioning of the rules or procedures for decision-making and collective conflict resolution". In contrast, interest groups are actors involved in the institutional fabric, but without sufficient power to determine changes in the rules of the game. This distinction is based on the capacity and power to exert influence on the functioning of the institutional framework in question. (Artazcoz et al., 20I0, p. 8)

The identification and characterization of the actors involved in each scenario requires their analytical development, specifying their nature in terms of the following aspects:

- Its category or formal level (national, provincial, municipal, non-governmental organizations);

- Its status (formal-informal/visible-invisible);

- Their beliefs or ideologies and mental maps;

- Modes of expression and action;

- Its organizational capacity and internal strength (in relation to coherence or cohesion as a social and political group or actor);

- Its core of formal and actual responsibilities or functions covered;

- Its space for intervention in the health system;

- Its position (opposing or facilitating) in relation to the program or policy in question.

The identification of the different types of resources controlled or mobilized by the actors includes symbolic, monetary, social capital or cultural capital resources. There is a relationship between actors, resources and power or capacity to influence the nature of the web of relationships, rules and procedures established. Thus, it is possible to 
recognize associations between the characteristics of actors and the type of resources involved. The type of resources controlled, their combination by an actor and his ability to mobilize them according to his own interests enhance his power to determine or change the rules of the game.

The methodology proposes a situational analysis of the relative power of the actors and requires a map that weighs the relational situation. It thus seeks to analyze the density of reciprocal relationships established and the nature of the transactions involved.

The methodology also refers to the study of the nature of the transactions involved, which may be negotiation, direction, sharing or reciprocity.

Rules. The construction of the rules of the game is a central dimension of governance. The arrangements between actors explain the institutional framework, which is made up of various rules (formal and informal) that guide the decisions and/or behavior of its actors. Rules play a dual role in the analysis of governance: they guide the behavior of actors and are modified by collective action.

Following Hufty, norms can be of three types, which in turn refer to different levels of analysis:

- First, meta-norms refer to premises or principles that guide the social contract in its broad sense, defining structural criteria and values.

- Secondly, the constitutive norms are those that define the organizational and institutional mechanisms related to the sectoral functioning of the object or scenario under analysis.

- Thirdly, regulative norms are those that define the rules of conduct that specify what is appropriate from society's point of view in terms of behavior, what everyone must or may do.

To analyze the processes of change of social norms, it is suggested to use a matrix that allows dividing the stages of the process of norm production, analyzing the different levels, and recognizing the mutual conditioning relationships

Nodal points are understood as the "social interfaces" defined in physical or virtual spaces (e.g., a negotiation table, the community council, etc.), where various processes, actors and norms converge, producing effects, in isolation or in interaction with others, on the dependent variable under study.

The identification of different nodal points, their characterization, relationships and their effects on the dependent variables make it possible to analyze the existing conditions (favorable or unfavorable) for a change process. This analysis aims at recognizing the formal and informal nodal points that are part of the web of decision-making spaces.

Processes are successions of states through which a system passes. They introduce the historicity of governance models. Thus, it is possible for a given object, or a nodal point, to identify sequences that make it possible to evaluate the direction in which these processes evolve and to locate the factors favorable to change. The analysis of change 
processes seeks to identify the patterns of evolution of nodal points, the web of interactions between actors and their relationship with changes in the rules of the game. The literature on health system governance reflects a broad frame of reference. A variety of definitions of health system governance can be found that are based on the broader concept of governance, and principles and dimensions of good practice for the health sector have been developed based on these definitions. There is also literature on the governance of the institutions that make up the health system.

USAID, for example, has argued that health system governance is governance conducted with the goal of protecting and promoting people's health. Governance involves "(I) setting strategic direction and objectives; (2) making policies, laws, rules, regulations, or decisions, and raising and deploying resources to achieve strategic goals and objectives; and (3) monitoring and ensuring that strategic goals and objectives are met." (López Ruiz et al., 2018, p.29). WHO included leadership in the concept. Leadership and governance involves ensuring that a strategic policy framework is in place and is combined with effective oversight, coalition building, regulation, attention to system design, and accountability. It requires oversight and guidance of the health system as a whole, not just the public system, to protect the public interest, which is broader than simply improving health status.

Subsequently, Siddiqi et al. expanded the list to ten components: strategic vision, participation and consensus orientation, rule of law, transparency, responsiveness, equity and inclusion, effectiveness and efficiency, accountability, intelligence and information, and ethics (Heras-Mosteiro et al., 2016, p. 186)

Not surprisingly, there are a variety of formulations of the functions needed to enable government to lead and direct the sector, to influence organizations and individuals involved in the financing, delivery and use of health services and health-related products, and to influence actors outside the health sector. sector whose actions affect population health. PAHO developed a list of II essential public health functions, while Veillard et al. described six types of actions needed to perform the governance function. In many ways, the different lists are very similar, with different degrees of aggregation of functions.

A team incorporating all the components that have been included in other lists proposes five broad actions, used as the basis for the development of the work plan in the following section:

Intelligence generation: information and analysis for decision making

Putting in place levers or tools to implement policies, including the design of health system organizational structures and their roles, powers and responsibilities; regulatory design; standard setting; incentives; enforcement and penalties

Collaboration and coalition building across sectors and with external partners.

Ensure accountability by establishing: governance structures, rules and processes for health sector organizations; independent oversight, monitoring, review and audit mechanisms; transparent availability and publication of policies, regulations, plans, 
reports, accounts, etc.; and openness to scrutiny by political representatives and civil society.

Siddiqi et al. took this further by developing a set of questions to assess governance in the 10 domains that the authors described and illustrated how they could be used to assess health system governance in Pakistan. This type of approach could be applied to particular components of the health system, e.g., human resources; health system financing; health service delivery; or to the system as a whole.

Work on the governance of health institutions rather than the health system in general refers to oversight and accountability arrangements for health sector institutions, such as hospitals or insurance agencies. They cover:

- The degree of autonomy in decision-making or discretion granted to

- The organization's managers, the rules that constrain them,

- The incentives that the organization and its managers face to fulfill their mandate,

- The organization's oversight and accountability arrangements, and checks and balances at the top of the organization.

Governance studies and interventions designed to improve governance at this level have covered, for example, hospitals primary care facilities mandatory social health insurance funds, central medical stores and the supply chain function for drugs and commodities, and regulatory agencies and functions, including drugs. regulatory agencies, professional licensing and disciplinary bodies, hospital accreditation agencies.

Research, analysis and advice on the governance of health sector institutions are often combined with assessment, advice and capacity building in management, while recognizing the distinction between management and governance functions. In many countries, addressing key gaps in management capacity and information systems is often a prerequisite for improving governance.

The following is an attempt to categorize the types of assistance and identify the different sources of technical assistance, studies and capacity building for the health sectors in developing countries delivered under the "governance" label.

Very few health centers have a specific strategy or program aimed at health systems governance as such. It is more common for their activities and programs to be focused on political, executive and

The strategies generally adopt a broad definition of governance combined with their own preferred list of characteristics of good governance, treating good governance as a desirable goal in its own right. Typically, these strategies adopt a broad definition of governance combined with their own preferred list of good governance characteristics, treating good governance as the goal, desirable in its own right. Some of the larger bilateral agencies have increasingly shifted the focus of their governance programs to fragile and conflict-affected states in recent years, including USAID, DFID and AusAID. Some agencies operate multisectoral governance-related programs that may cover the health sector. This is most common in the case of the World Bank and other multilateral development banks, which have large public sector management and private sector development programs that cover at least some aspects of governance. It is also a feature 
of development programs that support cross-sectoral policies of decentralization, community participation in governance and development, and social accountability. A variety of agencies (including GIZ, EU, DFID, World Bank, ADB, UNICEF, UNDP) provide support to individual sectors for the design, implementation or evaluation of decentralization and community participation in some types of governance activities.

Currently, the World Bank's governance-related strategy and work programs are primarily driven by its Governance and Public Sector Management group, although the International Finance Corporation (IFC), a member of the World Bank Group, also offers a private sector advisory service that "helps companies improve corporate governance, strengthen risk management," among other things.

Both public and private sector governance work streams have developed and implemented a number of governance-related diagnostics and interventions in the health sector. Several bilateral development partners contribute to Bank-administered governance trust funds that finance health sector governance activities.

Development agencies with health systems programs often also have a governance component, and most health systems strategies include some activities and objectives that fall within a broad or narrow definition of governance and leadership. These programs tend to treat governance interventions as "a means to the end" of achieving health system objectives, including UHC objectives. USAID, IDB, and World Bank health system programs and technical advice have addressed "narrow" governance of health financing institutions and health service delivery institutions and corruption in health systems, including informal payments and corruption among service providers. Agencies involved in health sector approaches and supporting the use of government systems to manage their health development assistance often support activities and objectives within the broad definition of governance, with a particular focus on capacity building and accountability of the state at the executive level. branch of government and public services. DFID, SIDA, the Netherlands, AusAID, the EU and the World Bank commonly provide public sector management and governance support in these contexts.

Pedro Francke (200I) discusses the health policy guidelines developed in Peru, highlighting that in the 1990s the supply of health services in first level facilities was substantially expanded, but without achieving efficiency or effectiveness and far from equity in access, which calls for immediate substantial changes in health policies, based on the fact that health is a right of all Peruvians and that fundamental reforms must be addressed: The democratization of the State, the prioritization of a set of health programs and services of effectively universal scope to reduce inequities, and the reorganization of health systems.

Health is a human right recognized in the 1946 Constitution of the World Health Organization, which states in one of its principles that the enjoyment of the highest attainable standard of health is one of the fundamental rights of every human being without distinction of any kind, such as race, religion, political ideology, economic or social condition, and in the Universal Declaration of Human Rights, article 25 of which states that everyone has the right to a standard of living adequate for the health and 
well-being of himself and of his family, including food, clothing, housing, medical care and necessary social services. This right is included in the Peruvian Constitution, which in Article 7 states that all Peruvians have the right to the protection of their health and in Article 9 states that the State determines the national health policy and must focus it as a dimension of development, where health is one of the social dimensions that enables the improvement of the quality of life of the population.

The right to health has different conceptions in the States, which prioritize some aspects of health over others, in order to overcome the fragmentation of these with respect to human rights and overcome the supremacy of civil and political rights over economic, social and cultural rights and advance in the construction of comprehensive health. Public policies, according to Peters, are: "the set of activities of government institutions, acting directly or through agents, and which are aimed at having a determined influence on the lives of citizens". (Díez et al., 2016, p- 75)

Thus, public policies are the main products of the government's function, which are used to condition the behavior of a society's agents according to specific objectives.

Politics is an abstraction that in the opinion of $M$. and G. Dimock "politics is solving problems in order to satisfy human needs. Politics is also to choose between alternatives, it is to make decisions; that is, about the content of the norms of action and values to be promoted, this is equivalent to saying that policy is the norm of conduct, this can mean, and often means, philosophical and value systems and other equally lofty abstractions", and adds "in public administration, policy is a process that affects all aspects of government operations and, as norms and systems are a seamless process, each of its aspects plays a role that is interrelated with all others" (Aranda \& Rodríguez, 2017, p. 760)

For Heras-Mosteiro et al., (2016)the political phenomenon is the result of "any action that has to do with the control of the state apparatus, with decision-making to impose beliefs and principles, with the struggle for power in its peaceful or violent form, with the legitimized authority, with the class struggle, with the legal-political order, with the theoretical justification of political praxis".

For his part Giné et al., (2020) says that "in general, politics is defined as only the power that in the State directs or leads, not the one that executes. As the depositary of political power is generally considered only the one that can carry out an essential change in the division of state power, internally or externally, on the basis of autonomous decisions, or strives to possess this power. That is why the activity of subordinate state organs, which is carried out according to precise rules, does not ordinarily count as politics "p. 3.

To conceptualize what democracy, politics and public policy are, I turn to the traditional dialogue between Alan and Beth that Roth A. Dahl writes in his text Democracy: A Citizen's Guide, Dahl refers to democracy as both an ideal and a reality. "Alan says: I think democracy is the best possible form of government and Beth replies: you must be crazy to think that the so-called democratic government of this country is the best we can have, heck, I don't even think it has much democratic in it. Dahl continues, Alan 
refers to democracy as an ideal, while Beth alludes to an effective government generally called democracy.

Unless Alan and Beth make it clear what meaning each of them is referring to, they will end up getting entangled in a dialogue of the deaf. I know from long experience how easy it is to fall into this-even, I regret to say, among colleagues with deep knowledge of democratic ideals and practices."

Indeed, there is democracy as a concept and as something ideal, and there is also the democracy that ordinary citizens experience on a daily basis, which is far from what an ideal or perfect democracy "should be". In the text by Philippe C Schmitter and Ferry Lynn Karl Karl: What is and what is not democracy? compiled by Sinesio López, Alberto Adrianzán and Julio Cotler, it is pointed out that "democracies are not necessarily more efficient economically than other forms of government, they are not necessarily more efficient administratively, that democracies probably do not appear more orderly, consensual, stable or governable than the dictatorships they replace".

In this scenario of the ideal and the real of democracy and politics, public policies are located as a very important tool that tries within the democratic and consensual guidelines to establish rules and forms of conduct in order to achieve efficiency, effectiveness and economy in achieving the objectives of government and society.

Hélan Jaworski C., professor at the PUCP, points out as a heterodox approach to the concept of public policies that, as guidelines that should organize the action of the state, "they are not chapters of a partisan plan or program, they are not the expression of electoral promises, nor necessarily the norms approved by the executive and legislative powers. They may be the above and much more, but by the fact of their existence they are not even a guarantee of progress or improvement of the national condition. It is therefore of interest to specify first of all what is public, its space and the way it is ordered and managed".

Repullo \& Freire, (2016) points out that "the confusion between public policy and public management is one of our most severe problems. Accepting beforehand that the border between the two terms is very blurred, public policy refers to "what to do" and public management to "how to do it "p. 6.

As can be seen, there are common elements in these definitions that apply to the field of public policy. In the first place, public policies are associated with the exercise of the power conferred on the government to achieve the ends of the State; consequently, whenever we speak of public policies, we are referring to those that emanate from the government, in its different instances, such as the ministries, supposedly to achieve the ends of the State. Secondly, they constitute an imposition of beliefs, values and principles, regardless of the forms in which they are carried out, on more or less numerous sectors of the population that at least initially do not share such ideas.

In view of the above, we assume that public policies are those courses of action selected as part of the strategic planning that the government approves and implements to fulfill the purposes of the State, which we identify with the national objectives of a nation, in a given geographical area and for a more or less lasting period of time. Public policies 
are "the framework through which national objectives are channeled into action, i.e., the principles that are to govern activities".

Patient care and attention

The care process is a set of actions, decisions, activities and tasks that are carried out in a sequential and orderly manner to achieve an outcome that fully satisfies the requirements of the intended user. A care process is usually visualized in the form of a flowchart or diagram, which describes in graphic form the way in which people carry out their work, the activities and interventions to be followed in different situations. It is important that comprehensive care is provided in each of the processes performed by health personnel, as this contributes to the continuous improvement of care.

Comprehensive patient care involves three fundamental elements: it looks at the individual as a biological, psychological, social and spiritual being; the second element is that comprehensive care is a process that has an interrelation between the individual and his or her environment; the third and last element identifies the components of the environment, which are the social, economic and cultural aspects.

This model of integral patient care is based on three attributes, with the aim of improving the warmth of health care; these are:

Timeliness: The user's ability to obtain the services he/she requires, without delays that could put his/her life or health at risk. This characteristic is related to the organization of the supply of services in relation to demand and to the level of institutional coordination to manage access to services.

Safety: It is the set of structural elements, processes, instruments and methodologies based on scientifically proven evidence that tend to minimize the risk of suffering an adverse event in the health care process or to mitigate its consequences (Portal Emedoriente, 2016).

\section{CONCLUSIONS}

The application of the governance analytical framework in health policy and systems research aims to achieve a better understanding of the political, social and institutional processes that determine the formulation and implementation of health programs. The use of a governance analytical approach seeks to recognize the constitutive and observable elements of the social processes associated with the policies under study. In this way, it distances itself from a normative approach based on the prescription of "ideal" and recommendable institutional models for health policies in Peru.

In order to advance in the development of the analytical framework of health governance, the conceptual categories described in this article were applied to a particular case of health research. The use of the categories defined as actors, norms, nodal points and processes has made it possible to systematize the analysis of the political and institutional complexity of the insurance implementation process. The analysis of the nodal points facilitated the methodological ordering and understanding of the decision-making processes, and made it possible to articulate the analysis of actors, norms and processes of change. 
Health promotion requires policy makers in all government departments to make health a central aspect of their policy.

This means that they must consider health implications in all their decisions, and prioritize policies that prevent people from getting sick or injured.

Health policies should be supported by regulations that combine private sector incentives with public health objectives, for example, by harmonizing tax policies that tax harmful or unhealthy products, such as alcohol, tobacco, and foods high in salt, sugars or fats, with measures to stimulate trade in

other areas. Legislation must also be enacted to support healthy urbanization by facilitating walking, reducing air and water pollution, and enforcing the mandatory use of helmets and seat belts.

Health governance requires strengthening health promotion and enabling people to take greater control of their own health. It encompasses a broad range of social and environmental interventions aimed at benefiting and protecting individual health and quality of life by preventing and addressing the root causes of health problems, rather than focusing solely on treatment and cure.

\section{REFERENCES}

Albar, M. J., \& Miranda, D. E. (2020). Advocacy for Roma health: in-service training of professionals from the Seville Health District. Gaceta Sanitaria, 34(4), 4I I-4I4. https://doi.org/I0.1016/j.gaceta.2019.07.010

Alcántara-Santuario, A., \& Marín-Fuentes, V. (20I3). Governance, democracy and citizenship: their implications with equity and social cohesion in Latin America. Revista Iberoamericana de Educación Superior, 4(10), 93-II 2. https://doi.org/l 0.1016/s2007-2872(I3)71926-7.

Americo, S. V. (20I3). Multidimensional water governance: the European Water Framework Directive. Difficulties in its implementation. Economia Informa, 38I, 74-90. https://doi.org/I0.1016/s0185-0849(13)71329-x.

Aranda, R., \& Rodríguez, I. (20I7). Governance of marine living resources through international law. Anuario Mexicano de Derecho Internacional, I 7(I), 75 I-784. https://doi.org/I0.2220I/iij.24487872e.2017.17.II05 I

Artazcoz, L., Oliva, J., Escribà-Agüir, V., \& Zurriaga, Ó. (2010). Health in all policies, a challenge for public health in Spain. SESPAS Report 2010. Gaceta Sanitaria, 24(SUPPL. I), I-6. https://doi.org/10.1016/j.gaceta.2010.10.006. https://doi.org//0.1016/j.gaceta.2010.10.006.

Cuervo, L. G., \& Bermúdez-Tamayo, C. (20I8). Development of research for health in Latin America and the Caribbean. Collaboration, publication and application of knowledge. Gaceta Sanitaria, 32(3), 206-208. https://doi.org//0.1016/j.gaceta.2018.03.00I.

Díaz-Castro, L., Arredondo, A., Pelcastre-Villafuerte, B. E., \& Hufty, M. (20I7). Governance indicators in mental health policies and programs in Mexico: a key actors' perspective. Gaceta Sanitaria, 3 I (4), 305-3I 2. 
https://doi.org/I0.1016/j.gaceta.2016.08.00I.

Díez, E., Aviñó, D., Paredes-Carbonell, J. J., Segura, J., Suárez, Ó., Gerez, M. D., Pérez, A., Daban, F., \& Camprubí, L. (2016). A good investment: health promotion in cities and neighborhoods. Gaceta Sanitaria, 30, 74-80. https://doi.org/I0.1016/j.gaceta.2016.04.015.

Giné, A., Morteruel, M., \& Martín, U. (2020). Incorporating narratives and perceptions into local health diagnoses: the case of Bilbao. Gaceta Sanitaria, $x x, 2-4$. https://doi.org/10.1016/j.gaceta.2020.10.002

Heras-Mosteiro, J., Otero-García, L., Sanz-Barbero, B., \& Aranaz-Andrés, J. M. (20I6). Perceptions of female and male primary care physicians in Madrid on adjustment measures in the public health system. Gaceta Sanitaria, 30(3), I84-190. https://doi.org/I0.1016/j.gaceta.2016.02.003

López, V., Segura, J., Pires, M. P., Malmusi, D., Vergara, M., \& Pérez, E. (2018). Municipalism and community health: transforming through local government. SESPAS Report 2018. Gaceta Sanitaria, 32, 26-31. https://doi.org//0.1016/j.gaceta.2018.06.007.

Morteruel, M., Bacigalupe, A., \& Moreno, A. (202I). Towards good governance for health: incorporating the diversity of perceptions around urban health. Gaceta Sanitaria, xx. https://doi.org/10.1016/j.gaceta.2020.II.003. https://doi.org/10.1016/j.gaceta.2020.11.003

Muñoyerro-Muñiz, D., Goicoechea-Salazar, J. A., García-León, F. J., Laguna-Téllez, A., Larrocha-Mata, D., \& Cardero-Rivas, M. (2020). Health record linkage: Andalusian health population database. Gaceta Sanitaria, 34(2), I05-II3. https://doi.org// 0.1016/j.gaceta.2019.03.003.

Pérez-Escamilla, R., Rizzoli-Córdoba, A., Alonso-Cuevas, A., \& Reyes-Morales, H. (2017). Advances in early childhood development: from neurons to big scale programs. Boletin Medico Del Hospital Infantil de Mexico, 74(2), 86-97. https://doi.org/I0.1016/j.bmhimx.2017.01.007.

Prada, J. (2013). The creativity and economy debate in today's cities and the role of different actors: some evidence from the case study of Madrid. Investigaciones Geográficas, Boletín Del Instituto de Geografia, 0(0), 62-75. https://doi.org/I0.I4350/rig.40700

Repullo, J. R., \& Freire, J. M. (2016). Implementing strategies to improve the institutional governance of the National Health System. Gaceta Sanitaria, 30, 3-8. https://doi.org/10.1016/j.gaceta.2016.04.016.

Valdés, J. L. (2016). Globalization vs. Sovereignty: Governance, War, or Progress, and World Order. North America, 07-43. https://doi.org/ 10.20999/nam.20 I5.b00 I 
